International Journal of Advanced Technology in Mechanical, Mechatronics and Materials

(IJATEC)

Vol. 01, No. 1 (2020) 13-17

(C) Institute for Research on Innovation and Industrial System (IRIS)

\title{
Design and Analysis of Ejector Pin in The Oil Seal Mould to Improve Its Mechanical Properties
}

\author{
Haris Wahyudi*a, Swandya Eka Pratiwia ${ }^{\mathrm{a}}$, Irwan Firdaus ${ }^{\mathrm{b}}$ \\ ${ }^{a}$ Department of Mechanical Engineering, Faculty of Engineering, Universitas Mercu Buana, Indonesia \\ ${ }^{b}$ Mechanical Engineering Bachelor Programme, Universias Mercu Buana, Indonesia
}

\begin{abstract}
Ejector pin in the mould is used to release (eject) the finished product, to vent gas out of the cavity and to expedite the material flow. It must have high strength, good hardness, good wear and corrosion resistance to withstand high pressure. Poor ejector pin may result in defect of finished product and delay the process due to additional time was required to release sticking product in the mould. The aim of this research is to select proper material for the ejector pin and analyse it not to experience plastic deformation. Three specimens' steel was considered for making the pin, SUS 304, normal SKS 3 and heat treated SKS 3. Hardness and tensile test were used to examine the mechanical properties of specimens and impact was utilized to obtain impact energy using Charpy method. Static stress analysis was also used to simulate the working load using SolidWorks. Rockwell hardness test recorded that SUS 304, normal SKS 3 and heat treated SKS have 23.2 HRC 9.6 HRC and 38.03 HRC, respectively. Tensile test produced yield strength of $452.9 \mathrm{MPa}$ for SUS 304 and $432.6 \mathrm{MPa}$ for SKS 3. Impact energy absorbed during Charpy test for SUS 304 equal to $0,804 \mathrm{~J} / \mathrm{mm}^{2}$ and specimen SKS 3 equal to $0,863 \mathrm{~J} / \mathrm{mm}^{2}$. By taking the mechanical test result and SolidWorks simulation, it was concluded that the suitable material for ejector pin is SUS 304.
\end{abstract}

Keywords: ejector pin; SUS 304; SKS 3; impact test, SolidWorks; stress analysis

DOI: $10.37869 /$ ijatec.v1i1.8

Received 4 March 2020; Accepted 19 March 2020; Available online 30 March 2020

(c) 2020 IRIS Publisher. All rights reserved.

\section{Introduction}

The final step in the injection moulding process is ejection of a product component [1]. The quality of the ejection determines the quality of the product [2]. Since the component is tightly bound by the cavity of the mould, it creates constraining forces between them [3]. This induces friction at the mould-part interface which causes the part to stick to the mould. Therefore, after opening the mould, an ejection mechanism is needed for part removal. Thus, ejector pin is required to release the product when the mould opens during the finishing process.

There are some criteria that should be considered in mould design and process to minimize defects [4]-[7]. To prevent deformation, the ejection force must be uniformly distributed, there are several ejection pins installed at certain location [8]. The force of ejection should be applied to the part with the strongest strength and rigidity (avoid on thin section). Sticking product to the mould can be avoided using proper ventilation mainly in the ejector pin [8], [9]. It prevents high ejection force that may result in deformation of both product and ejector pin. Selection of ejector pin material is critical; it must have good strength and wear resistance because during the ejection process, ejector pin obtain high load. The ejection system that poorly designed may damage the product, cause defects such as indentation [6]. Ejector pins may experience plastic deformation or even break during operations incurring production shutdown and maintenance cost [10].

*Corresponding author: haris.wahyudi@mercubuana.ac.id ISSN: 2720-9008 


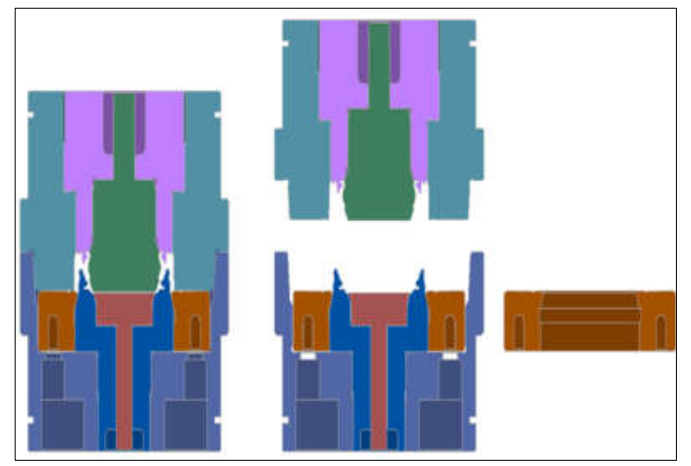

Figure 1. Mould and ejector pin design

Figure 1 depicts the sectional view of mould design with ejector pins. The ejector pins are in the lower half of the mould, the side where the part will stay when the mould opens. After opening the mould, the pins extend into the cavity of the mould, force the product out and then retract, enabling the mould to close and be refilled [11].

\section{Research Methodology}

The material for ejector pins were made of SUS 304 and SKS 3 steel. SUS 304 consist of two main alloying elements that are $\mathrm{C}$ and $\mathrm{Ni}$ with the composition of $0.1 \mathrm{wt} \%$ and $30 \mathrm{wt} \%$, respectively. SKS 3 has $0.95 \mathrm{wt} \% \mathrm{C}, 0.25 \mathrm{wt} \% \mathrm{Si}, 1.05 \mathrm{wt} \% \mathrm{Mn}$, and others element, $\mathrm{P}, \mathrm{S}, \mathrm{Cr}$ and $\mathrm{W}$ as shown in Table 1. Two different specimens of SKS 3 were used, one specimen was hardened using heat treatment process and the other was not. Heat treatment was conducted by heating specimen in the furnace at $800^{\circ} \mathrm{C}$ for about 60 minutes and then quenched into oil.

Table 1. Chemical composition of SKS 3 [12] and SUS 304 [13]

\begin{tabular}{|l|c|c|c|c|c|c|c|c|c|c|}
\hline \multirow{2}{*}{ JIS Grade } & \multicolumn{10}{|c|}{ Chemical Composition (wt\%) } \\
\cline { 2 - 20 } & $\mathrm{C}$ & $\mathrm{Si}$ & $\mathrm{Mn}$ & $\mathrm{Ni}$ & $\mathrm{P}$ & $\mathrm{S}$ & $\mathrm{Cr}$ & $\mathrm{Mo}$ & $\mathrm{W}$ & $\mathrm{V}$ \\
\hline SUS 304 & $0.08-0.1$ & $\leq 1$ & $\leq 2$ & $8-10.5$ & & & $18-20$ & & & \\
\hline SKS 3 & 0.95 & 0.25 & 1.05 & - & $\leq 0.03$ & $\leq 0.02$ & 0.7 & - & 0 & - \\
\hline
\end{tabular}

Rockwell hardness test, tensile test and impact test were used to determine mechanical properties of specimens. It was expected for SKS 3 specimen that mechanical properties significantly improved. Hardness value were tested using Rockwell method at minimum three different locations. Yield strength, tensile strength, and ductility (\%EL) was obtained from tensile test. Charpy impact test was used to measure impact energy, the amount of energy absorbed by specimen to break the material. SolidWorks software was used to perceive stress analysis, distribution of stress receives by specimens [14], [15]. Some numerical simulation was developed to predict forces and total ejection forces during injection moulding [16], [17].

\section{Results and Discussions}

The Rockwell hardness result are shown in Table 2. Normal SKS 3 has the lowest value of hardness 9.6 HRC, SUS 304 in second 23.2 HRC and hardened SKS 3 has the highest hardness 38.0 HRC. Heat treatment of SKS 3 has significant effect to improve the hardness. Having carbon of $0.95 \%$, SKS 3 is considered a hyper-eutectoid steel (high carbon steel) where hardening mechanism is done by phase transformation accompanying quenching into oil. Rapid cooling results in the transformation of austenite into non-equilibrium products at a considerably low temperature.

Impact energy for specimens were evaluated by Charpy test as shown in Table 3. Impact test determines the amount of energy absorbed by a specimen during fracture. Charpy specimen has area under V-notch of $80 \mathrm{~mm}^{2}$. During the impact test, the energy absorbed were $69.03 \mathrm{~J}$ (SUS 304) and 
64.32 J (SKS 3). After divided by area, both specimens nearly have same value of impact energy per area, $0.86 \mathrm{~J} / \mathrm{mm}^{2}$ for SUS 304 and $0.80 \mathrm{~J} / \mathrm{mm}^{2}$ for SKS 3. The higher value of impact energy per area indicates higher toughness of material, the component is resistance to fracture.

Table 2. Rockwell Hardness test result

\begin{tabular}{ccccc}
\hline Material & $\begin{array}{c}\text { Point 1 } \\
\text { (HRC) }\end{array}$ & $\begin{array}{c}\text { Point 2 } \\
\text { (HRC) }\end{array}$ & $\begin{array}{c}\text { Point 3 } \\
\text { (HRC) }\end{array}$ & $\begin{array}{c}\text { Average } \\
\text { (HRC) }\end{array}$ \\
\hline SUS 304 & 22.6 & 23.2 & 23.7 & 23.2 \\
SKS 3 & 9.0 & 10.5 & 9.4 & 9.6 \\
SKS 3 (HT)* & 38.7 & 39.5 & 35.9 & 38.0 \\
\hline *HT: heat treated & & & &
\end{tabular}

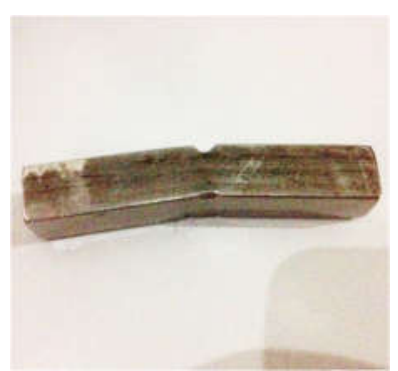

a. Before impact

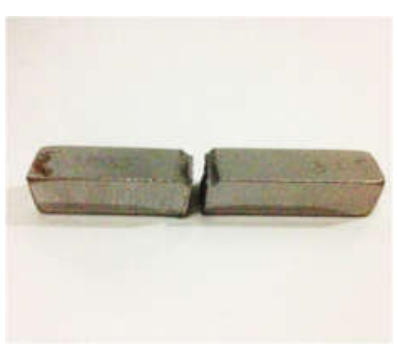

b. After impact

Figure 2. Specimen for impact test

Table 3. Charpy impact energy result

\begin{tabular}{cccc}
\hline Material & $\begin{array}{c}\text { Specimen area } \\
\text { under impact }\left(\mathrm{mm}^{2}\right)\end{array}$ & $\begin{array}{c}\text { Impact energy } \\
(\mathrm{J})\end{array}$ & $\begin{array}{c}\text { Impact energy/area } \\
\left(\mathrm{J} / \mathrm{mm}^{2}\right)\end{array}$ \\
\hline SUS 304 & 80 & 69.03 & 0.86 \\
SKS 3 & 80 & 64.32 & 0.80 \\
\hline
\end{tabular}

The result of tensile test is shown in Table 4. Cylinder specimens were tensile tested until fractured and stress-strain graph were plotted. Initial diameter and length for SUS 304 is respectively $6.6 \mathrm{~mm}$ and $35 \mathrm{~mm}$; for SKS 3 is $6.7 \mathrm{~mm}$ and $35 \mathrm{~mm}$. Yield and tensile strength of SUS $304\left(\sigma_{y}=452.9\right.$ $\left.\mathrm{MPa}, \sigma_{t s}=716.16 \mathrm{MPa}\right)$ is slightly higher than SKS $3\left(\sigma_{y}=432.64 \mathrm{MPa}, \sigma_{t s}=663.64 \mathrm{MPa}\right)$. It is obvious that the strength of SUS 34 better than SKS 3 as well as ductility, can be seen from the percent elongation.

Table 4. Tensile test result

\begin{tabular}{ccccccccc}
\hline Specimens & $\begin{array}{c}\text { Diameter } \\
(\mathrm{mm})\end{array}$ & $\begin{array}{c}\text { Initial } \\
\text { Area } \\
\left(\mathrm{mm}^{2}\right)\end{array}$ & $\begin{array}{c}\text { Initial } \\
\text { length } \\
(\mathrm{mm})\end{array}$ & $\begin{array}{c}\text { Max. } \\
\text { Load } \\
(\mathrm{kN})\end{array}$ & $\begin{array}{c}\text { Yield } \\
\text { Stress } \\
(\mathrm{MPa})\end{array}$ & $\begin{array}{c}\text { Tensile } \\
\text { stress } \\
(\mathrm{MPa})\end{array}$ & $\begin{array}{c}\text { Elongation } \\
(\mathrm{mm})\end{array}$ & $\begin{array}{c}\text { Percent } \\
\text { elongation } \\
(\%)\end{array}$ \\
\hline SUS 304 & 6.6 & 34.21 & 35 & 24.5 & 452.9 & 716.16 & 12 & 34 \\
SKS 3 & 6.7 & 35.26 & 35 & 23.4 & 432.64 & 663.64 & 8 & 22 \\
\hline
\end{tabular}




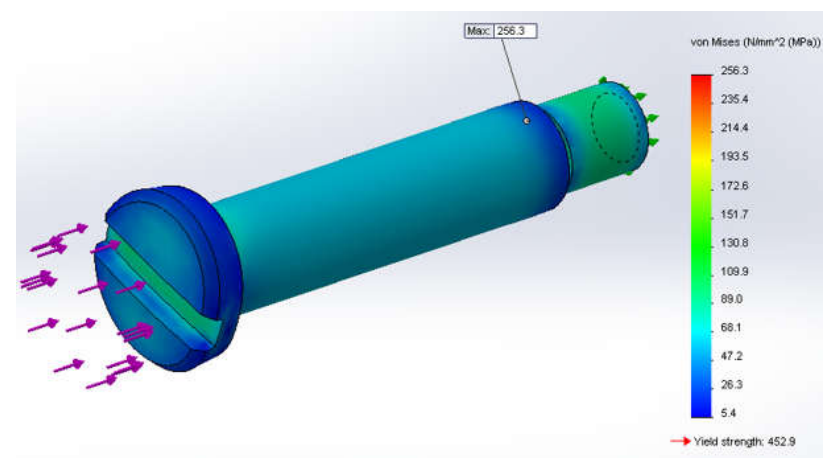

Figure 3. Stress analysis result for SUS 304

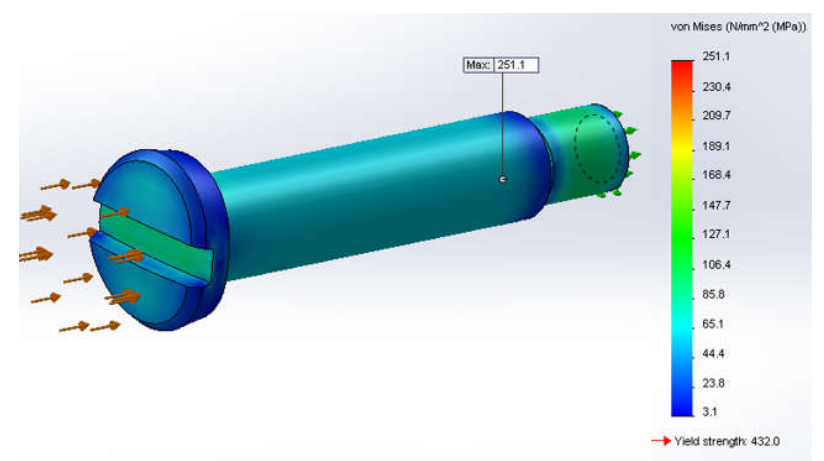

Figure 4. Stress analysis result for SKS 3

Static stress simulation was conducted in SolidWorks to obtain stress distribution using Von Mises criterion. The result is shown in Figure 3 and Figure 4. The maximum Von Mises stress obtained is 256.3 MPa and 251.1 MPa, respectively for SUS 304 and SKS 3. The compressive force imposed on the PIN ejector causes stress or tension where the maximum stress is in the thread feature. As mentioned in the previous result, yield strength $\left(\sigma_{y}\right)$ for SUS 304 and SKS 3 is $452.9 \mathrm{MPa}$ and 432.64 $\mathrm{MPa}$, respectively. It is true that both specimens have higher value of yield strength compare to Von Mises stress. Generally, specimens of SUS 304 generally has superior properties than SKS 3.

\section{Conclusions}

From the mechanical test result, specimen SUS 304 is preferably selected compare to SKS 3, hardness value (23.2 HRC), yield strength $452.9 \mathrm{MPa}$, impact energy $0.86 \mathrm{~J} / \mathrm{mm}^{2}$. The applied stress of SUS 304 specimen (256.3 MPa) is much lower to its yield strength, plastic deformation will not occur. The combination of high hardness, yield strength and impact energy per area make SUS 304 is best candidate for ejector pins.

\section{References}

[1] S. R. S. Serope Kalpakjian, Manufacturing Processes for Engineering Materials. 2007.

[2] D. F. Heaney, Handbook of Metal Injection Molding. 2012.

[3] H. Wang, K. K. Kabanemi, and G. Salloum, "Numerical and experimental studies on the ejection of injection-molded plastic products," Polym. Eng. Sci., 2000.

[4] D. Mathivanan, M. Nouby, and R. Vidhya, "Minimization of sink mark defects in injection molding process - Taguchi approach," Int. J. Eng. Sci. Technol., 2010.

[5] K. H. Tan and M. M. F. Yuen, "A Fuzzy multiobjective approach for minimization of injection molding defects," Polym. Eng. Sci., 2000.

[6] W. J. Tseng and D. Chiang, "Influence of molding variables on defect formation and mechanical strength of injection-molded ceramics," J. Mater. Process. Technol., 1998.

[7] J. R. Lerma Valero and J. R. Lerma Valero, "Defects in Injection Molded Parts," in Plastics Injection Molding, 2020.

[8] J. M. Mercado-Colmenero, M. A. Rubio-Paramio, A. Vizan-Idoipe, and C. Martin-Doñate, "A new 
procedure for the automated design of ejection systems in injection molds," Robot. Comput. Integr. Manuf., 2017.

[9] M. Rosen, "Good Venting," Plast. Eng., 2015.

[10] D. Agung and H. Hasbullah, "Reducing the Product Changeover Time using SMED \& 5S Methods in the Injection Molding Industry," SINERGI, 2019.

[11] D. O. Kazmer, Injection mold design engineering. 2007.

[12] SteelJIS Japanese Steels and Alloys, "SKS 3 Chemical composition, standards and properties," 2018. [Online]. Available: http://steeljis.com/jis_steel_datasheet.php.

[13] S. J. S. and Alloys, "SUS 304 Chemical composition, standards and properties," 2018. [Online]. Available: http://steeljis.com/jis_steel_datasheet.php.

[14] A. B. Setiawan and S. E. Pratiwi, "Perancangan dan Analisa Tegangan Separator Produksi Menggunakan Software PV Elite dan Solidworks," J. Tek. Mesin, 2018.

[15] M. I. Bakalova, "Application of SolidWorks Plastic in the Training in Mechanical Engineering," Annu. J. Tech. Univ. VARNA, Bulg., 2017.

[16] O. M. Bataineh and B. E. Klamecki, "Prediction of local part-mold and ejection force in injection molding," J. Manuf. Sci. Eng. Trans. ASME, 2005.

[17] T. Barriere, D. Renault, and J. C. Gelin, "Experimental and numerical analysis of the effects of process parameters on the properties of components in metal injection molding," in Journal De Physique. IV : JP, 2001. 